\title{
MENENTUKAN FAKTOR-FAKTOR YANG MEMILIKI HUBUNGAN MINAT MAHASISWA STEI SEBI MENABUNG DI SEBI ISLAMIC BANK
}

\author{
Hendi Mulyana \\ (Alumni STEI SEBI) \\ $\&$ \\ Mustafa Kamal \\ (Dosen STEI SEBI)
}

\begin{abstract}
Abstraksi
Sekolah Tinggi Ekonomi Islam (STEI) SEBI mendirikan sebuah lembaga keuangan syariah. Lembaga keuangan tersebut bernama SEBI ISLAMIC BANK (SIB). SIB berdiri atas dasar pemikiran akan pentingnya suatu lembaga intermediari finansial internal kampus STEI SEBI. Lembaga ini pada awalnya mempunyai maksud mempermudah arus keuangan sekaligus mengembangkan instuisi produktif para pengelola, staff dan mahasiswa STEI SEBI khususnya, serta masyarakat di lingkungan STEI SEBI pada umumnya.

Seiring dengan bertambahnya jumlah mahasiswa STEI SEBI tiap tahunnya, tentu menjadi peluang bertambah pula jumlah nasabah SIB. Namun pada kenyataannya mahasiswa yang menabung di SIB masih sedikit.

Penelitian ini bertujuan untuk mengetahui pengaruh minat mahasiswa STEI SEBI menabung di Sebi Islamic Bank (SIB). Sumber data dalam penelitian ini adalah data primer yang diperoleh melalu kuesioner dari sebagian mahasiswa angkatan 2008-2011.

Teknik pengumpulan data dilakukan dengan survei. Data diperoleh dengan menggunakan kuesioner yang disebar kepada sebagian mahasiswa angkatan 20082011 sebagai sampel baik itu program studi Perbankan Syariah maupun Akuntansi Syariah. Untuk menentukan jumlah sampel penulis menggunkan rumus Slovin, yang mana dari hasil rumus Slovin tersebut dapat diketahui jumlah sampel yang ditentukan sebesar 85 responden dari angkatan 2008-2011 yang berjumlah 535 mahasiswa. Pemilihan sampel dilakukan dengan metode random sampling. Teknik analisis data menggunakan pengujian melalui Uji Validitas dan Reliabilitas data, Chi-Square, serta analisis CHAID.
\end{abstract}

Kata Kunci : Lembaga Keuangan Mikro Islam, Metode CHAID 


\begin{abstract}
Sekolah Tinggi Ekonomi Islam (STEI) SEBI has been establishing a shariah financial institutions. The institution namely SEBI ISLAMIC BANK (SIB). SIB has been establishing based on reasoning the urgency of financial intermediary institution internal campus STEI SEBI. Initially the institution had sole to facilitate cash flow both developing productiveness institution manager, staff and students STEI SEBI particularly and society at STEI SEBI generally.
\end{abstract}

Along with increasing the number of students STEI SEBI every year, it would be good opportunity to increase a number of customer SIB. But the fact students who saved at SIB were still slightly.

This research had goal to find out the influence students STEI SEBI who saved on Sebi Islamic Bank (SIB). Data sources in this research were primer data that had been obtainable by questioners from part of students 2008-2011.

A technique to collect data has been done by survey. Data achieved by questioners that spread to part of students 2008-2009 as sample both majoring Islamic Banking and Islamic accounting. In order to determine number of samples, writer used Solvin's formula where the result could be discovered the number of samples as 85 respondents from 2008-2011 which amounts 535 students. Determining of samples had been done by sampling random method. Data analysis technique used examination through validation and reliability data, Chi-Square, and CHAID analysis.

Keywords : Islamic Microfinance, CHAID Methode, 


\section{PENDAHULUAN}

\subsection{Latar Belakang}

Pada tahun 1967 praktek bank syariah direalisasikan dalam dunia Islam pertama kali oleh Mith Ghamr Bank Mesir yang dipelopori oleh para pelaku bisnis dari kalangan jama'ah Ikhwanul Muslimin. Dalam perkembangannya bank ini tidak berumur panjang, akibat konflik politik antara jama'ah tersebut dengan pemerintah Mesir. Namun ia merupakan tonggak dan pelopor yang kemudian memberikan inspirasi pada praktekpraktek perbankan sesuai dengan prinsip-prinsip syariah di negeri Islam lainnya. Pada tahun 1975 didirikan Islamic Development Bank yang operasionalnya dimaksimalkan sesuai dengan prinsip-prinsip syariah dengan tujuan meningkatkan kesejahteraan negara Islam diseluruh dunia. Sehingga dari awal tahun 1980-an hingga awal tahun 1990-an praktek perbankan syariah menyebar di hampir seluruh negeri muslim. (Ali sakti, 2007, hal. 287-288)

Menurut Sukarmadji (2009), perbankan syariah masih mempunyai beberapa kendala yang dapat menghambat pertumbuhan, diantaranya: Pertama, pemahaman publik tentang perbankan syariah. Penyebab utama lambannya perkembangan bank syariah di Indonesia adalah ketidak pedulian masyarakat Indonesia terhadap kontrak Islam (FIQH MUAMALAT) pada umumnya dan praktik bank Islam pada khususnya. Kedua, masalah jaringan. Kurangnya jaringan artinya bahwa keberadaannya hanya di wilayah yang terbatas, dimana cabang-cabang bank syariah berdiri, masyarakat dapat menyimpan dana mereka. Ketiga, adalah sumber daya manusia (SDM). Bank Syariah saat ini masih kekurangan sumberdaya manusia yang menguasai aspek fiqih tentang perbankan syariah dan pengetahuan manjemen perbankan praktis. Hal ini terutama dirasakan pada unit usaha syariah di bank konvesional, karena sebagian besar karyawannya adalah karyawan bank konvesional yang dipekerjakan di bank syariah dengan hanya diberikan pelatihan secukupnya, sehingga menyebabkan kurang mengertinya mereka tentang sistem perbankan syariah secara menyeluruh (Febrian, 2009, hal. 3).

Permasalahan SDM dapat diselesaikan melalui peran lembaga pendidikan. Hal ini dikarenakan lembaga pendidikan berfungsi sebagai lembaga yang memberikan softskill dan hardskill kepada calon SDM, agar dapat mewujudkan visi dan misi perbankan syariah. Salah satu lembaga pendidikan tersebut adalah Sekolah Tinggi Ekonomi Islam SEBI yang mempunyai visi "Terdepan dalam Pengembangan Ekonomi dan Lembaga Keuangan Syariah" (SEBI, 2008-2009, hal. 4). Berikut perkembangan jumlah mahasiswa dapat dilihat pada grafik. 


\section{Grafik 1.2}

Perkembangan Jumlah Mahasiswa STEI SEBI Pertahun/Angkatan

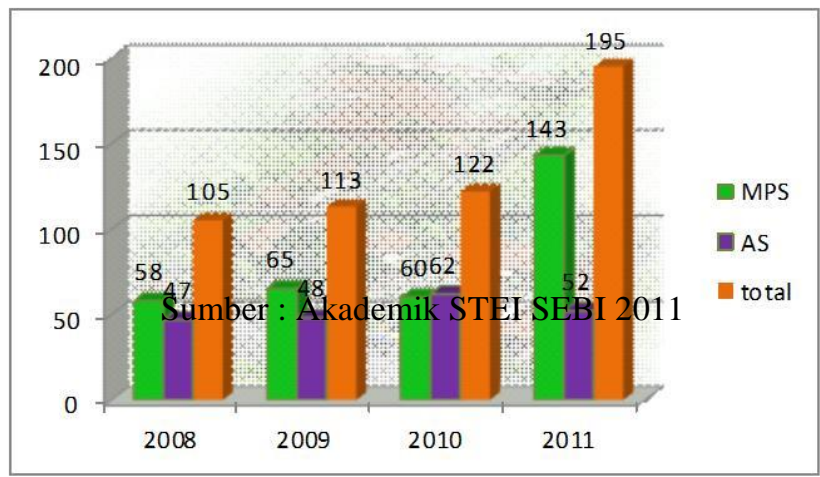

Grafik 1.2 menjelaskan total mahasiswa angkatan 2008-2011 berjumlah 535 mahasiswa yang terdiri atas 326 mahasiswa Manajemen Perbankan Syariah dan 209 mahasiswa Akuntansi Syariah. Meningkatnya jumlah mahasiswa membuktikan bahwa STEI SEBI konsisten dalam kontribusi menciptakan SDM ekonomi syariah. Selain itu, untuk mewujudkan visinya STEI SEBI mendirikan lembaga intermediari keuangan bernama Sebi Islamic Bank (SIB). SIB berdiri pada tanggal 1 Mei 2003 dan mulai beroperasi 1 Juli 2004. SIB berdiri atas dasar pemikiran akan pentingnya suatu lembaga intermediari finansial internal kampus SEBI. Lembaga ini pada awalnya mempunyai maksud mempermudah arus keuangan sekaligus mengembangkan intuisi produktif para pengelola, staf dan mahasiswa STEI SEBI khususnya, serta masyarakat di lingkungan STEI SEBI pada umumnya (SIB, 2011). Akan tetapi dari jumlah mahasiswa STEI SEBI yang menabung di SIB hanya sebagian kecil yaitu 117 orang dari total mahasiswa sebanyak 535 orang. Dapat dilihat pada tabel dan grafik berikut.

Tabel 1.2

Jumlah Mahasiswa menabung di SIB perangkatan dari 2008-2011

\begin{tabular}{cccc}
\hline No & Angkatan & $\begin{array}{c}\text { Jumlah yang } \\
\text { Menabung }\end{array}$ & $\begin{array}{c}\text { Jumlah yang } \\
\text { tidak menabung }\end{array}$ \\
\hline $\mathbf{1}$ & 2008 & 37 orang & 68 orang \\
$\mathbf{2}$ & 2009 & 40 orang & 73 orang \\
$\mathbf{3}$ & 2010 & 20 orang & 102 orang \\
$\mathbf{4}$ & 2011 & 20 orang & 175 orang \\
\hline & Jumlah & 117 orang & 418 orang \\
\hline
\end{tabular}


Tabel 1.2 menjelaskan bahwa jumlah mahasiswa yang menabung paling banyak adalah angkatan 2009 dengan jumlah 40 orang menabung(35\%) dan 73 orang tidak menabung (65\%). Sedangkan jumlah yang terendah adalah angkatan 2011 yaitu 20 orang menabung (10\%) dan 175 orang tidak menabung (90\%). Masih sedikitnya mahasiswa yang menabung di SIB sebagaimana yang akan dijelaskan pada grafik berikut.

\section{Grafik 1.3}

Jumlah Mahasiswa STEI SEBI yang Menabung dan Tidak Menabung di SIB

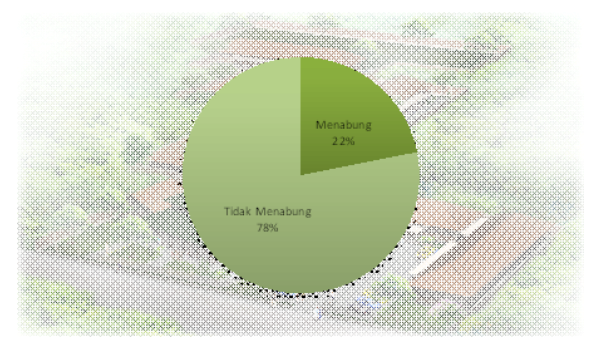

Sumber: SEBI ISLAMIC BANK 2011 (data diolah)

Grafik 1.3 menjelaskan total mahasiswa yang menabung di SIB adalah 117 orang $(22 \%)$ dan yang tidak menabung 418 orang (78\%). Seiring dengan bertambahnya jumlah mahasiswa STEI SEBI tiap tahunnya, tentu menjadi peluang bertambah pula jumlah nasabah SIB. Namun pada kenyataannya mahasiswa yang menabung di SIB masih sedikit.

Penulis memandang persoalan ini penting untuk diteliti, agar pihak SIB dapat mengetahui apa yang menjadi faktor penyebab minat mahasiswa menabung dan tidak menabung di SIB. Oleh karena itu, penelitian yang akan dilaksanakan ini berjudul "Menentukan Faktorfaktor yang Memiliki Hubungan Minat Mahasiswa STEI SEBI Menabung di SEBI ISLAMIC BANK" Studi kasus mahasiswa STEI SEBI angkatan 2008-2011.

\subsection{Tujuan Penelitian}

1) Untuk mengetahui faktor apa saja yang memiliki hubungan minat mahasiswa STEI SEBI menabung di Sebi Islamic Bank.

2) Untuk mengetahui faktor mana yang paling memiliki hubungan minat mahasiswa STEI SEBI menabung di Sebi Islamic Bank. 


\subsection{Manfaat Penelitian}

Hasil penelitian ini diharapkan dapat bermanfaat bagi Sebi Islamic Bank untuk mengetahui minat para mahasiswa STEI SEBI menabung dan tidak menabung di Sebi Islamic Bank sehingga kedepannya bisa meningkatkan minat mahasiswa untuk menabung dan manfaatnya menabung di Sebi Islamic Bank.

\section{TINJAUAN PUSTAKA}

\subsection{Faktor-faktor yang memiliki hubungan minat menabung mahasiswa}

Perilaku seseorang menabung di lembaga keuangan(bank) dipengaruhi oleh beragam alasan, mulai dari reputasi bank yang baik sehingga membuat anda merasa aman, tingkat suku bunga atau margin simpanan yang relatif tinggi, hadiah mewah yang ditawarkan, kantor yang tersebar diberbagai tempat sehingga membuat kemudahan nasabah dalam bertansaksi dimanapun dan kapanpun, sampai pelayanan (service) nasabah yang baik (Kertajaya, 2006, hal. 44). Dari beragam alasan tersebut, minat menabung yang memiliki hubungan ada 3 faktor yaitu, faktor budaya, sosial, dan kepribadian. Faktor budaya meliputi kebiasaan dalam satu kelompok baik itu ras atau suku, agama, kebangsaan, dan wilyah geografis. Faktor sosial meliputi keluarga, dan pengaruh lingkungan (masyarakat atau teman). Yang terakhir faktor pribadi meliputigaya hidup, latar belakang pendidikan, lokasi, kemudahan, dan rasa aman (Kotler, 2009, hal. 166).

Adapun Kontler menjelaskan faktor-faktor yang memiliki hubungan minat menabung adalah sebagai berikut:

1. Faktor Budaya

Budaya (culture) adalah nilai, pemikiran, serta simbol yang mempengaruhi perilaku, sikap, kepercayaan, serta kebiasaan seseorang maupun masyarakat.

2. Faktor Sosial

Faktor sosial dapat mempengaruhi minat menabung seseorang seperti keluarga, teman, kerabat, tetangga dan rekan kerja yang berinteraksi dengan seseorang secara terus menerus dan informal.

3. Faktor Kepribadian

Keputusan menabung di Bank Syariah juga dipengaruhi oleh karakteristik pribadi. Faktor pribadi meliputi gaya hidup, latar belakang pendidikan, kemudahan, dan rasa aman. Setiap orang mempunyai karakteristik pribadi yang mempengaruhi perilaku keinginannya (minat). Yang dimaksud dengan kepribadian (personality), adalah sekumpulan sifat psikologis manusia yang menyebabkan respons yang relatif kiosisten dan tahan lama terhadap rangsangan lingkungan. 


\subsection{Pengertian Minta}

Pengertian minat dalam kamus besar Bahasa Indonesia adalah kecenderungan hati yang tinggi terhadap sesuatu, gairah, ataupun keinginan (Nasional, 2007, hal. 744).

Minat menurut Dr. Agus Sujanto dalam bukunya, ialah suatu fungsi jiwa untuk dapat mencapai sesuatu. Minat ini merupakan kekuatan dalam diri. Dan tampak dari luar sebagai gerak gerik. Dalam fungsinya minat ini bertautan dengan fikiran dan perasaan (Sujanto, 2004, hal. 84).

Dari pengertian kedua minat di atas, dapat disimpulkan bahwa minat adalah kecenderungan hati yang tinggi terhadap sesuatu untuk mencapai apa yang diinginkan dan biasanya bertautan dengan pikiran dan perasaan.

\subsection{Metode Chi-square Automatic Interaction Detection (CHAID) \\ CHAID adalah singkatan dari Chi-SquaredAutomatic Interaction}

Detector. CHAID pertama kali diperkenalkan dalam sebuah artikel berjudul "AnExploratory Technique for Investigating LargeQuantities of Categorical Data" oleh Dr. G.V. Kasstahun 1980. Prosedurnya merupakan bagian dari teknik terdahulu yang dikenal dengan Automatic Interaction Detector (AID), dan menggunakan statistik Chi-Square sebagai alat utamanya.

CHAID secara keseluruhan bekerja untuk menduga sebuah variabel tunggal, disebut sebagai variabel dependen, yang didasarkan pada sejumlah variabel-variabel yang lain. CHAID merupakan suatu teknik interatif yang menguji satu-persatu variabel independen yang digunakan dalam klasifikasi, dan menyusunnya berdasarkan pada tingkat signifikansi statistik Chi-Square terhadap variabel dependennya (Gallagher, 2000).

CHAID digunakan untuk membentuk segmentasi yang membagi sebuah sampel menjadi dua atau lebih kelompok yang berbeda berdasarkan sebuah kriteria tertentu. Hal ini kemudian diteruskan dengan membagi kelompok-kelompok tersebut menjadi kelompok yang lebih kecil berdasarkan variabel independen yang lain. Prosesnya berlanjut sampai tidak ditemukan lagi variabel independen yang signifikan secara statistik. Segmen-segmen yang dihasilkan akan bersifat saling lepas yang secara statistik akan memenuhi kriteria pokok segmentasi dasar (Bagozzi, 1994). Hasilnya juga akan memberikan peringkat pada variabel yang merupakan variabel independen paling signifikan sampai yang tidak signifikan.

CHAID memilih variabel independennya atas dasar uji Chi-Square antara kategori variabel yang tersedia dengan kategori-kategori variabel dependennya (seperti yang terdapat pada statistika dasar bahwa uji ChiSquare merupakan uji non parametrik yang sesuai untuk menguji hubungan antar variabel yang berbentuk kategori) (Myers, 1996). 
Pada dasarnya, dari beberapa definisi CHAID diatas dapat disimpulkan bahwa CHAID adalah sebuah metode untuk mengklasifikasikan data kategori dimana tujuan dari prosedurnya adalah untuk membagi rangkaian data menjadi subgrup-subgrup berdasarkan pada variabel dependennya (Yohanes Sondang Kunto dan Inggried Kurniawan Khoe, 2007, hal. 89).

Rumus dasar Chi-Kuadrat (Chi-Square) adalah :

$$
X^{2}=\sum \frac{\left(f_{0}-f_{e}\right)^{2}}{f_{e}}
$$

Dimana :

$$
\begin{array}{ll}
\mathrm{X}^{2} & =\text { Chi Kuadrat } \\
\mathrm{f}_{\mathrm{o}} & =\text { Frekuensi yang diobservasi } \\
\mathrm{f}_{\mathrm{e}} & =\text { Frekuensi yang diharapkan }
\end{array}
$$

\subsection{Pengertian BMT}

Baitul Maal Wattamwil (BMT) merupakan suatu lembaga yang terdiri dari dua istilah, yaitu baitul maal dan baitul tamwil. Baitul maal lebih mengarah pada usaha-usaha pengumpulan dan penyaluran dana yang nonprofit, seperti zakat, infaq, dan sedekah. Adapun baitul tamwil sebagai usaha pengumpulan dan penyaluran dana komersial. Usaha-usaha tersebut menjadi bagian yang tidak terpisahkan dari BMT sebagai lembaga pendukung kegiatan ekonomi masyarakat kecil dengan berlandaskan Islam. Lembaga ini didirikan dengan maksud untuk memfasilitasi masyarakat bawah yang tidak terjangkau oleh pelayanan Bank Islam atau BPR Islam. Perinsip oprasinya didasarkan atas prinsip bagi hasil, jual beli (ijarah), dan titipan (wadiah). Karena itu, meskipun mirip dengan Bank Islam, BMT memiliki pangsa pasar tersendiri, yaitu masyarakat kecil yang tidak terjangkau layanan perbankan serta pelaku usaha kecil yang mengalami hambatan "psikologis" bila berhubungan dengan pihak bank (Heykal, 2010, hal. 363).

\subsection{Saving (Menabung)}

Simpanan adalah dana yang dipercayakan oleh masyarakat kepada bank dalam bentuk giro, deposito berjangka, sertifikat deposito, tabungan, atau bentuk lainnya yang disamakan dengan itu. Pola konsumsi yang diatur dalam Islam memungkinkan ummatnya untuk menyisihkan sebagian dari pendapatnya untuk kegiatan ibadah dan muamalah. Oleh karena itu ummat Islam dapat memberikan kepercayaan kepada Bank Islam untuk menyimpan dananya itu dalam bentuk Giro Wadiah atau diinvestasikan dalam bentuk Deposito Mudharabah dan Tabungan Mudharabah. (H. Karnaen A. Perwataatmadja, 1992)

\subsection{Tujuan Menabung}

Tujuan menabung adalah untuk investasi selanjutnya atau untuk tujuan lain. Misalnya, pengumpulan dana guna membeli barang-barang 
mahal (big ticket item) dikemudian hari, penyediaan cadangan guna mengantisipasi kemungkinan keperluan belanja yang tidak terduga, penyediaan dana pensiun, atau dapat juga karena kesenangan menimbun uang seperti Silas Marner*) yang kikir. (Johnson, 2003, hal. 220)

Apalah arti tabungan bila tidak diinvestasikan. Ia hanya menjadi seonggok harta yang tidak berguna. Islam tidak menyukai adanya tindakan penimbunan harta yang sia-sia ini. Di satu pihak Islam memberikan disinsentif terhadap saving yang tidak diinvestasikan, namun di pihak lain Islam memberikan insentif untuk melakukan investasi. Konsekuensi logis dari investasi adalah munculnya peluang untuk untung dan rugi. (Karim, 2007, hal. 97)

Imam Ghazali mengecam orang yang menimbun harta dan tidak ditransaksikan atau diputar di sektor riil "jika seseorang menimbun dinar dan dirham, ia berdosa. Dinar dan dirham tidak memiliki guna langsung pada dirinya. Dinar dan dirham diciptakan supaya beredar dari tangan ke tangan, untuk mengatur dan memfasilitasi pertukaran...[sebagai] simbol untuk mengetahui nilai dan kelas barang. Siapapun yang mengubahnya menjadi peralatan-peralatan emas dan perak tidak bersyukur kepada penciptanya dan lebih buruk dari pada penimbun uang, karena orang yang seperti itu adalah seperti orang yang memaksa penguasa untuk melakukan fungsi-fungsi yang tidak cocok, seperti menenun kain, mengumpulkan pajak dan lain-lain. Menimbun koin masih lebih baik dari pada mengubahnya, karena ada logam dan material lainnya seperti tembaga, perunggu, besi, tanah liat yang dapat digunakan untuk membuat peralatan. Tetapi tanah liat tidak dapat digunakan untuk mengganti fungsi yang dijalankan oleh dirham dan dinar. (Karim, 2007, hal. 99)

\section{METODOLOGI PENELITIAN}

\subsection{Jenis Penelitian}

Jenis penelitian yang penulis gunakan adalah kuantitatif. Penelitian kuantitatif dapat diartikan sebagai metode penelitian yang berlandaskan pada filsafat positivisme, digunakan untuk meneliti pada populasi atau sampel tertentu, teknik pengambilan sampel pada umumnya dilakukan secara random, pengumpulan data menggunakan instrumen penelitian, analisis data bersifat kuantitatif/statistik dengan tujuan untuk menguji hipotesis yang telah ditetapkan (Sugiyono, 2009, hal. 13).

Penelitian yang penulis teliti adalah faktor-faktor minat mahasiswa menabung di SIB. Variabel mandiri dalam penelitian ini yaitu faktor yang mempengaruhi mahasiswa untuk menabung di SIB. Untuk memudahkan dalam pembahasan tersebut, peneliti berusaha memahami karakteristik minat mahasiswa menabung, mulai dari faktor lokasi, fasilitas, margin (bagi hasil) dan produk, dengan mengumpulkan data-data terkait dengan 
studi pustaka, kuesioner, dan wawancara langsung dengan mahasiswa STEI SEBI.

\subsection{Jenis Data}

Menurut jenisnya data terbagi atas dua yaitu, data primer dan data sekunder. Data primer adalah data yang diperoleh peneliti dari sumber asli. Dalam hal ini, maka proses pengumpulan datanya perlu dilakukan dengan memerhatikan siapa sumber utama yang akan dijadikan objek penelitian. Dengan demikian, pengumpulan data primer merupakan bagian integral dari proses penelitian ekonomi yang digunakan untuk pengambilan keputusan. Data primer dapat dikumpulkan melalui observasi, eksperimen, maupun kuesioner (daftar pertanyaan). Sedangkan data sekunder adalah data yang diperoleh dalam bentuk asli yang sudah jadi, sudah dikumpulkan dan diolah oleh pihak lain, biasanya sudah dalam bentuk publikasi. (Muhammad, 2008, hal. 103).

\subsection{Teknik pengumpulan data}

a. Data sekunder

Data sekunder yang penulis gunakan dalam penelitian ini adalah pertama penulis mengumpulkan data yang diambil dari referensi buku yang berkaitan dengan pembahasan dalam penelitian ini, kedua profil lembaga keuangan SIB, ketiga Annual Report yaitu statistik perbankan Indonesia (Bank Indonesia), data jumlahmahasiswa STEI SEBI dari angkatan 2008-2011, dan data mahasiswa menabung di SIB dari angkatan 2008-2011.

b. Data Primer

Untuk data primer, penulis akan menyebarkan kuesioner ke sejumlah mahasiswa yang telah ditentukan dari angkatan 20082011. Selanjutnya penulis akan melakukan FGD (Focus Group Discussion) sebagai pelengkap data primer yaitu, diskusi kepada sebagian responden tentang minat menabung yang penulis telah tentukan. FGD tersebut hampir sama dengan wawancara.

\subsection{Populasi Dan Sampel}

a. Populasi

Populasi adalah wilayah generalisasi yang terdiri atas obyek/subyek yang mempunyai kualitas dan karakteristik tertentu yang ditetapkan oleh peneliti untuk dipelajari dan kemudian ditarik kesimpulannya (Sugiyono, 2009, hal. 115). Populasi pada penelitian ini adalah seluruh mahasiswa STEI SEBI dari angkatan 2008-2011. Adapun jumlah mahasiswa STEI SEBI ialah sebagai berikut: 
13 Jurnal Ekonomidan Perbankan Syariah

Tabel 3.1

Perkembangan Jumlah Mahasiswa STEI SEBI 2011-2012

\begin{tabular}{|c|c|c|c|}
\hline No & & Prodi & Jumlah Mahasiswa \\
\hline \multirow[t]{2}{*}{1} & 2008 & Perbankan Syariah & 58orang \\
\hline & & Akuntansi Syariah & 47orang \\
\hline \multirow[t]{2}{*}{2} & 2009 & Perbankan Syariah & 65orang \\
\hline & & Akuntansi Syariah & 48orang \\
\hline \multirow[t]{2}{*}{3} & 2010 & Perbankan Syariah & 60orang \\
\hline & & Akuntansi Syariah & 62orang \\
\hline \multirow[t]{3}{*}{4} & 2011 & Perbankan Syariah & 143 orang \\
\hline & & Akuntansi Syariah & 52orang \\
\hline & \multicolumn{2}{|c|}{ Jumlah } & 535 orang \\
\hline
\end{tabular}

Sumber: Akademik STEI SEBI

Tabel 3.1 menjelaskan jumlah seluruh mahasiswa STEI SEBI yang akan menjadi populasi dalam penelitian ini adalah 535 orang. Dari seluruh jumlah tersebut, penulis akan tarik sampel sebagai keterwakilan perangkatan dari seluruh jumlah mahasiswa angkatan 2008-2011.

\section{b. Sampel}

Sampel merupakan bagian atau sejumlah cuplikan tertentu yag diambil dari suatu populasi dan diteliti secara rinci (Muhammad, 2008, hal. 162). Dalam arti lain sampel adalah bagian dari jumlah dan karakteristik yang dimiliki oleh populasi tersebut. Bila populasi besar, dan peneliti tidak mungkin mempelajari semua yang ada pada populasi, misalnya karena keterbatasan dana, tenaga dan waktu, maka peneliti dapat menggunakan sampel yang diambil dari populasi itu. Apa yang dipelajari dari sampel itu, kesimpulannya akan dapat diberlakukan untuk populasi. Untuk itu sampel yang diambil dari populasi harus betul-betul representatif atau mewakili (Sugiyono, 2009, hal. 116).

\subsection{Penentuan Ukuran Sampel}

Untuk menentukan ukuran sampel dalam penelitian ini, penulis menggunakan rumus slovin dalam menentukan jumlah sampel mahasiswa yang menabung dan tidak menabung di SIB, sebagaimana berikut (Muhammad, 2008, hal. 180).

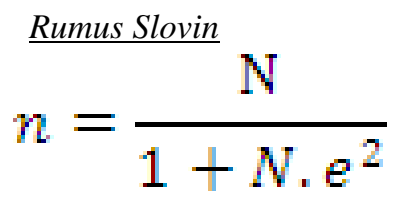
di mana:

$\mathrm{n}=$ ukuran sampel

$\mathrm{N}=$ ukuran populasi

$\mathrm{E}=$ persen kelonggaran ketidak telitian karena kesalahan pengambilan sampel yang masih dapat ditoleri atau diinginkan, misalnya $10 \%$ 
$14 \mid J u r n a l$ Ekonomi dan Perbankan Syariah

Diketahui jumlah populasi

$(\mathrm{N})=535$, persentase kelonggaran $10 \%$.

Ditanyakan sampel (n)

Hitung:

$$
\begin{aligned}
& \mathrm{n}=\frac{535}{1+535 \cdot(0,1)} \\
& \mathrm{n}=\frac{535}{6,35}
\end{aligned}
$$

\subsection{Teknik Sampling}

Teknik sampling adalah merupakan teknik pengambilan sampel. Untuk menentukan sampel yang akan digunakan dalam penelitian terdapat berbagai teknik sampling yang digunakan, yaitu Probability Sampling dan Nonprobability Sampling.

Teknik pengumpulan sampel yang penulis gunakan adalah teknik Probability Sampling yaitu, teknik pengambilan sampel yang memberikan peluang yang sama bagi setiap unsur (anggota) populasi untuk dipilih menjadi anggota sampel. Teknik ini meliputi, Sampel Random Sampling, Proportionate Stratified Random Sampling, Disproportionate Stratified Random Sampling, Sampling Area (Cluster) Sampling (Sampling Menurut Daerah).

Teknik pengumpulan sampel Probability sampling untuk penelitian ini penulis menggunakan teknik Proportionate Stratified Random Sampling, yaitu tenik yang digunakan bila populasi mempunyai anggota/unsur yang tidak homogen dan berstrata secara proporsional (Sugiyono, 2009, hal. 116). Adapun sampel yang penulis teliti adalah keterwakilan perangkatan mahasiswa STEI SEBI angkatan 2008-2011 yang menabung dan tidak menabung di SIB.

\subsection{Instrumen Penelitian}

Instrumen penelitian adalah segala peralatan yang digunakan untuk memperoleh, mengolah, dan menginterprestasikan informasi dari para responden yang dilakukan dengan pola pengukuran yang sama (Muhammad, 2008, hal. 114).

Tabel 3.2

Sub Variabel dan Indikator Minat Mahasiswa STEI SEBI Menabung di SEBI ISLAMIC BANK

\begin{tabular}{|l|l|l|}
\hline Sub Variabel & Indikator & No. Item \\
\hline Faktor Pribadi & Latar belakang pendidikan & $1, \mathrm{~s} / \mathrm{d} 18$ \\
& Gaya hidup hemat & \\
& Penghasilan tambahan & \\
& Beasiswa & \\
& Keuntungan & \\
& Kemudahan & \\
& Rasa aman & \\
& Investasi & \\
& Tempat tinggal & \\
& Lokasi & \\
\hline
\end{tabular}


15 Jurnal Ekonomidan Perbankan Syariah

\begin{tabular}{|c|c|c|}
\hline & Motivasi & \\
\hline Faktor Budaya & $\begin{array}{l}\text { Adat Istiadat (kebiasaan) } \\
\text { Pengaruh suku/ras } \\
\text { Kepercayaan terhadap nilai-nilai Islam } \\
\text { Kelas sosial (status) } \\
\text { Saran dari MUI dan lembaga pendidikan ekonomi } \\
\text { syariah }\end{array}$ & 19, s/d 24 \\
\hline Faktor Sosial & $\begin{array}{l}\text { Pengaruh masyarakat atau lingkungan } \\
\text { Pengaruh teman } \\
\text { Pengaruh organisasi } \\
\text { Pengaruh dosen } \\
\text { Pengaruh keluarga (Ibu, Ayah \& Sodara) } \\
\text { Sosialisasi dari kalangan petinggi perbankan syariah }\end{array}$ & $25, \mathrm{~s} / \mathrm{d} 31$ \\
\hline
\end{tabular}

Sumber: Dikembangkan dari kotler, Manajemen Pemasaran, 2009.

Variabel penelitian yang akan penulis analisis adalah minat mahasiswa STEI SEBI menabung di SIB. Adapun sub variabel dalam penelitian ini adalah faktor budaya, faktor sosial, dan faktor pribadi. Subvariabel tersebut mencakup beberapa indikator yang penulis ambil dari pendapat kotler (Kotler, 2009, hal. 166).

Tabel 3.2 menjelaskan sub variabel dari Minat Mahasiswa STEI SEBI Menabung di SIB ada tiga yaitu Faktor Pribadi, Faktor Budaya, dan Faktor Sosial. Yang mana dari masing-masing faktor tersebut muncul indikator yang menjadi item pertanyaan dalam kuesioner

\subsection{Analisis Data}

Sebelum penulis menyebarkan kuesioner kepada responden, penulis akan menguji kuesioner tersebut dengan menggunkan uji validitas dan uji reabilitas supaya setiap pertanyaan mudah di pahami dan menghasilkan hasil yang tepat dan baik.

\section{a. Uji Validitas}

Validitas merupakan derajad ketepatan antara data yang sesungguhnya terjadi pada objek penelitian dengan data yang dapat dilaporkan oleh peneliti. Dengan demikian data valid adalah data "yang tidak berbeda" antara data yang dilaporkan oleh peneliti dengan data yang sesungguhnya terjadi pada obyek penelitian (Sugiyono, 2009, hal. 455).

Uji validitas diguakan untuk mengetahui seberapa cermat dan tepat suatu kuesioner dalam melakukan fungsi ukurnya. Semakin tinggi nilai validitasnya maka semakin kecil juga tingkat kesalahannya.

\section{b. Uji Reliabilitas}

Reliabilitas berkenaan dengan derajad konsistensi dan stabilitas data atau temuan. Dalam pandangan positivistik (kuantitatif), suatu data dinyatakan reliabel apabila dua atau lebih peneliti dalam obyek yang sama menghasilkan data yang sama, atau peneliti sama dalam waktu berbeda menghasilkan data yang sama, atau sekelompok data bila dipecah 
menjadi dua menunjukkan data yang tidak berbeda (Sugiyono, 2009, hal. 456).

Reliability adalah tingkat kemantapan atau konsistensi suatu alat ukur. Apabila suatu alat pengukuran telah dinyatakan secara valid, maka tahapan berikutnya adalah mengukur reliabilitas. Hasil penelitian dikatakan reliabel jika hasil penelitian tersebut mendapatkan hasil yang sama jika dilakukan berulang. Contohnya: jika peneliti satu menemukan dalam obyek berwarna merah, maka peneliti yang lain juga demikian atau seorang peneliti dalam obyeknya kemarin menemukan data warna merah, maka sekarang atau besok akan tetap berwarna merah.

Setelah kuesioner yang di uji valid, selanjutnya penulis menggunakan analisis Chi-Square untuk mengetahui estimasi atau dugaan terhadap ada tidaknya perbedaan frekuensi antara kategori satu dan kategori yang lain dalam sebuah sampel tentang sesuatu hal (Sugiyono, 2009, hal. 295). Setelah analisis Chi-Square dilakukan tahap selanjutnya adalah analisis CHAID, yaitu analisis yang digunakan untuk membentuk segmentasi yang membagi sebuah sampel menjadi dua atau lebih kelompok yang berbeda berdasarkan sebuah kriteria tertentu. Hal ini kemudian diteruskan dengan membagi kelompok-kelompok tersebut menjadi kelompok yang lebih kecil berdasar kanvariabel-variabel independen yang lain (Yohanes Sondang Kunto dan Inggried Kurniawan Khoe, 2007, hal. 25). Pada penelitian ini analisis CHAID digunakan untuk menganalisis faktor minat mahasiswa menabung di SIB.

\section{ANALISIS \& PEMBAHASAN \\ Gambaran Umum Karakteristik Responden}

Dalam penelitian ini, penulis mengambil sampel sebanyak 85 responden dari seluruh mahasiswa STEI SEBI angkatan 2008-2011 yang berjumlah 535 mahasiswa. Adapun dari kuesioner yang penulis sebar menghasilkan jumlah penabung adalah 51 responden dan tidak menabung 34 responden, sehingga kalau ditotal jumlahnya adalah 85 responden. Persentase responden yang penulis ambil dari angkatan 2008-2011 yang berjumlah 85 responden berdasarkan jenis kelamin digambarkan pada tabel berikut.

Tabel 4.1,

JumlahSampel Responden yang Menabung dan Tidak Menabung di SIB

\begin{tabular}{|c|c|l|l|l|}
\hline \multirow{2}{*}{ No } & \multirow{2}{*}{ Angkatan } & \multicolumn{2}{|c|}{ Jenis Kelamin } & \multirow{2}{*}{ Total } \\
\cline { 3 - 4 } & & \multicolumn{1}{|c|}{ Laki-laki } & \multicolumn{1}{|c|}{ Perempuan } & \\
\hline 1 & 2008 & $19(22.35 \%)$ & $13(15.30 \%)$ & $32(37.65 \%)$ \\
\hline 2 & 2009 & $14(16.47 \%)$ & $9(10.59 \%)$ & $23(27.06 \%)$ \\
\hline 3 & 2010 & $4(4.71 \%)$ & $7(8.24 \%)$ & $11(12.94 \%)$ \\
\hline 4 & 2011 & $16(18.82 \%)$ & $3(3.52 \%)$ & $19(22.35 \%)$ \\
\hline & Total & $53(62.35 \%)$ & $32(37.65 \%)$ & $85(100 \%)$ \\
\hline
\end{tabular}

Sumber : Kuesioner penelitian Minat Mahasiswa STEI SEBI 2008-2011 Menabung di SIB 
Tabel diatas menunjukan jumlah responden yang mengisi kuesioner perangkatan. Total responden angkatan 2008 adalah 32 responden $(37.65 \%)$, dengan kategori jenis kelamin laki-laki berjumlah 19 responden $(22.35 \%)$, perempuan berjumlah 13 responden $(15.30 \%)$. Total responden angkatan 2009 adalah 23 responden (27.06\%), dengan kategori jenis kelamin laki-laki berjumlah14 responden (16.47\%), perempuan berjumlah 9 responden $(10.59 \%)$. Total responden angkatan 2010 adalah 11 responden (12.94\%), dengan kategori jenis kelamin lakilaki berjumlah 4 responden $(4.71 \%)$, perempuan berjumlah 7 responden (8.24\%). Total responden angkatan 2011 adalah 19 responden $(22.35 \%)$, dengan kategori jenis kelamin laki-laki berjumlah 16 responden $(18.82 \%)$, perempuan berjumlah 3 responden $(3.52 \%)$. Berdasarkan tabel di atas dan hasil perhitungan rumus Slovin yang telah dilakukan menunjukan bahwa, data contoh yang digunakan cukup representatif dengan jumlah populasi yang ada.

\subsection{UJI VALIDITAS \& REALIBILITAS}

\section{a. Uji Validitas}

Kualitas data yang dihasilkan instrumen penelitian dapat diuji dengan menggunakan validitas dan reabilitas. Pengujian validitas dilakukan terhadap pertanyaan-pertanyaan dalam kuesioner untuk mengukur variabel Pribadi, Budaya dan Sosial. Pengujian validitas dalam penelitian menggunakan alat uji SPSS 15.00 for Windows. Asumsi yang digunakan dalam uji validitas adalah uji signifikansi dilakukan dengan membandingkan $r$ hitung dengan $r$ tabel untuk degree of freedom $(\mathrm{df})=n$ - 2, dimana $n$ adalah jumlah sampel dan besarnya df dapat dihitung 11-2 $=9$, dengan $\mathrm{df}=9$, dan alpha 0.05 , jika $\mathrm{r}$ hitung lebih besar dari $\mathrm{r}$ tabel maka $r$ hitem dinyatakan valid (Ghazali, 2005, hal. 45).

Setelah dilakukan uji validitas pada instrumen Pribadi, terdapat 5 butir pertanyaan yang tidak valid, yaitu Pribadi 3, Pribadi 7, Pribadi 9, Pribadi 14 dan pribadi19 dikarenakan nilai rata-ratanya dibawah standar yaitu 0,075-0,209. Maka pengujian validitas harus kembali diuji dengan mengeluarkan setiap butir pertanyaan yang dianggap tidak valid. Hasil uji kualitas data pada instrumen motivasi berdasarkan output SPSS sebagaimana table berikut:

Uji Validitas Variabel Pribadi

\begin{tabular}{|l|c|c|}
\hline No. Item & $\begin{array}{c}\text { Taraf } \\
\text { Signifikan }\end{array}$ & Keterangan \\
\hline Pribadi1 & 0,294 & Valid \\
\hline Pribadi2 & 0,413 & Valid \\
\hline Pribadi4 & 0,333 & Valid \\
\hline
\end{tabular}


18|Jurnal Ekonomidan Perbankan Syariah

\begin{tabular}{|l|l|l|}
\hline Pribadi5 & 0,271 & Valid \\
\hline Pribadi6 & 0,343 & Valid \\
\hline Pribadi8 & 0,355 & Valid \\
\hline Pribadi10 & 0,355 & Valid \\
\hline Pribadi11 & 0,281 & Valid \\
\hline Pribadi12 & 0,404 & Valid \\
\hline Pribadi13 & 0,474 & Valid \\
\hline Pribadi15 & 0,622 & Valid \\
\hline Pribadi16 & 0,552 & Valid \\
\hline Pribadi17 & 0,474 & Valid \\
\hline Pribadi18 & 0,385 & Valid \\
\hline
\end{tabular}

Uji Validitas Variabel Budaya

\begin{tabular}{|c|c|c|}
\hline No. Item & Taraf Signifikan & Keterangan \\
\hline Budaya1 & 0,489 & Valid \\
\hline Budaya2 & 0,336 & Valid \\
\hline Budaya3 & 0,504 & Valid \\
\hline Budaya4 & 0,290 & Valid \\
\hline Budaya5 & 0,601 & Valid \\
\hline Budaya6 & 0,301 & Valid \\
\hline
\end{tabular}

Uji Validitas Variabel Sosial

\begin{tabular}{|c|c|c|}
\hline No. Item & Taraf Signifikan & Keterangan \\
\hline Sosial 1 & 0,467 & Valid \\
\hline Sosial 2 & 0,315 & Valid \\
\hline Sosial 3 & 0,466 & Valid \\
\hline Sosial 4 & 0,564 & Valid \\
\hline Sosial 5 & 0,344 & Valid \\
\hline Sosial 6 & 0,517 & Valid \\
\hline Sosial 7 & 0,519 & Valid \\
\hline
\end{tabular}

\section{b. Uji Reliabilitas}

Asumsi yang digunakan dalam uji reliabilitas adalah ONE SHOT atau pengukuran sekali saja. Pengukuran reliabilitas ini menggunakan SPSS dengan uji statistik Cronbach"s Alpha. Suatu konstruk atau variabel dikatakan reliabel jika memberikan nilai Cronbach"s Alpha > 0,60 (Ghazali, 2005, hal. 42).

Tabel 4.5, Uji Reliabilitas Pribadi, Budaya dan Sosial

Reliability Statistics

\begin{tabular}{|c|r|}
\hline $\begin{array}{c}\text { Cronbach's } \\
\text { Alpha }\end{array}$ & $\mathrm{N}$ of Items \\
\hline, 648 & 14 \\
\hline
\end{tabular}

*Pribadi
Reliability Statistics

\begin{tabular}{|r|r|}
\hline $\begin{array}{c}\text { Cronbach's } \\
\text { Alpha }\end{array}$ & N of Items \\
\hline, 624 & 6 \\
\hline
\end{tabular}

*Budaya
Reliability Statistics

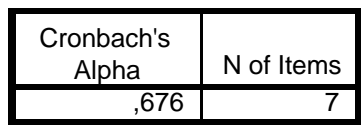

*Sosial 
Dari tabel diatas maka dapat disimpulkan bahwa data yang dikumpulkan melalui instrumen tersebut adalah reliabel karena instrumen Pribadi memiliki nilai cronbach"s alpha diatas 0,60 yaitu sebesar 0,648, instrumen Budaya memiliki nilai cronbach"s alpha diatas 0,60 yaitu sebesar 0,624 dan Begitupun dengan instrumen Sosial memiliki nilai cronbach"s alpha diatas 0,60 yaitu sebesar 0,676.

Hasil dari uji validitas dan reliabilitas, tahap selanjutnya yaitu analisis Chi-Square dan analisis CHAID untuk menentukan hasil dari penelitian ini yaitu faktor-faktor mana yang memiliki hubungan terhadap minat mahasiswa STEI SEBI menabung di Sebi Islamic Bank.

\section{c. Hasil Analisis Dengan Metode Chi-Square}

Tingkat faktor yang memiliki hubungan antara minat mahasiswa menabung di SIB diuji dengan menggunakan Chi-Square (Khi-Kuadrat) dengan taraf nyata 0,05 Nilai Chi-Square hitung lebih besar dari taraf nyata 0,05 maka terdapat faktor yang memilki hubungan antara minat mahasiswa menabung di SIB dan sebaliknya apabila nilai Chi-Square hitung lebih kecil dari taraf nyata 0,05 maka tidak terdapat hubungan minat mahasiswa menabung di Sebi Islamic Bank.

Faktor yang memiliki hubungan dengan minat mahasiswa menabung di SIB dalam pengolahan data yang digunakan berupa kategori diskret yakni menabung dilambangkan dengan angka 1 dan tidak menabung dilambangkan dengan angka 0 . Adapun faktor yang memiliki hubungan terhadap minat mahasiswa menabung di SIB adalah Kost, Jarak, gaya hidup hemat, uang saku, penghasilan tambahan, beasiswa STEI SEBI, beasiswa dari luar, menabung di lembaga keuangan syariah, latar belakang pendidikan, keuntungan, kemudahan, keamanan, investasi, adat istiadat (kebiasaan), suku atau ras, kepercayaan terhadap lembaga keuangan syariah, nilai-nilai islami, saran MUI, saran dosen, saran kampus sendiri (STEI SEBI), saran Keluarga, status sosial, faktor masyarakat lingkungan sekitar banyak yang menabung di lembaga keuangan syariah, faktor teman dan teman organisasi yang banyak menabung di lembaga keuangan syariah terutama SIB, pengaruh sosialisasi para petinggi perbankan syariah, produk yang unik, bagi hasil non bunga (margin), kemudahan dalam mengajukan pembiayaan, dan alasan uang saku yang tidak cukup.

Berdasarkan dari analisis penulis ada 6 faktor dari 31 indikator yang memiliki hubungan terhadap minat mahasiswa STEI SEBI menabung di SIB berdasarkan perbandingan Chi-Square hitung dengan Chi-Square tabel. Ke enam faktor tersebut adalah jarak tempuh tempat tinggal dengan kampus, pengaruh lingkungan tempat tinggal, produk tabungan yang unik dan tidak unik, sistem bagi hasil non riba, pengaruh uang saku, dan pengaruh banyaknya teman yang menabung di SIB, yang lebih jelasnya bisa dilihat di tabel berikut. 
Tabel 4.37

Sembilan Faktor Hasil Chi-Square yang Memiliki Hubungan Terhadap Minat Mahasiswa STEI SEBI menabung di Sebi Islamic Bank

\begin{tabular}{|l|l|c|c|}
\hline No & \multicolumn{1}{|c|}{ Faktor } & $\mathbf{X}^{\mathbf{2}}$ hitung & $\boldsymbol{X}^{\mathbf{2}}$ Tabel 0,10 (1) \\
\hline $\mathbf{1}$ & Produk Unik & 18,739 & 3,841 \\
\hline $\mathbf{2}$ & Sistem Bagi Hasil & 18,739 & 3,841 \\
\hline $\mathbf{3}$ & Uang Saku Tidak Cukup & 9,882 & 3,841 \\
\hline $\mathbf{4}$ & Teman & 9,692 & 3,841 \\
\hline $\mathbf{5}$ & Tempat Tinggal Dekat Dengan Kampus & 7,783 & 3,841 \\
\hline $\mathbf{6}$ & Lingkungan Tempat Tinggal & 7,290 & 3,841 \\
\hline
\end{tabular}

Sumber: Data diolah dengan menggunakan SPSS 15

Tabel 4.37 menunjukan faktor-faktor yang memiliki hubungan terhadap minat mahasiswa menabung di Sebi Islamic Bank. Data tersebut dapat dilihat dari nilai $X^{2}$ hitung lebih besar dari nilai $X^{2}$ tabel, sehingga faktor tersebut menunjukan yang memiliki hubungan terhadap minat mahasiswa STEI SEBI menabung di Sebi Islamic Bank.

\section{d. Hasil Analisis dengan Metode CHAID}

Analisis CHAID menghasilkan suatu dendogram yang memetakan penggabungan berdasarkan hubungan terstruktur antara faktor-faktor yang memiliki hubungan menabung dengan minat mahasiswa menabung di Sebi Islamic Bank. Proses penggabungan dan penyekatan dengan metode CHAID pada kasus ini menggunakan standar batas taraf nyata sebesar 0.05 , titik induknya 20 dan titik cabangnya 5. Penetapan induk 20 dan cabang 5 mengacu pada pernyataan dalam persyaratan pengolahan data menggunakan metode Chi-Square, untuk menghindari uji Fisher-Irwin (Kamal, 2010, hal. 33). Uji Fisher adalah untuk menguji signifikansi hipotesis komparatif dua sampel kecil independen bila datanya berbentuk nominal. Kecil dalam hal ini, bilamana jumlah kedua sampel $(n 1+n 2)<$ 20. Sedangkan untuk sampel yang besar (jumlahnya $>20$ ), data contoh harus berukuran besar sekurang-kurangnya memiliki frekuensi harapan 510 pada setiap sel atau titik induk 20 dan cabang 5 (Sugiyono, 2007). Dedogram hasil metode CHAID berikut : 


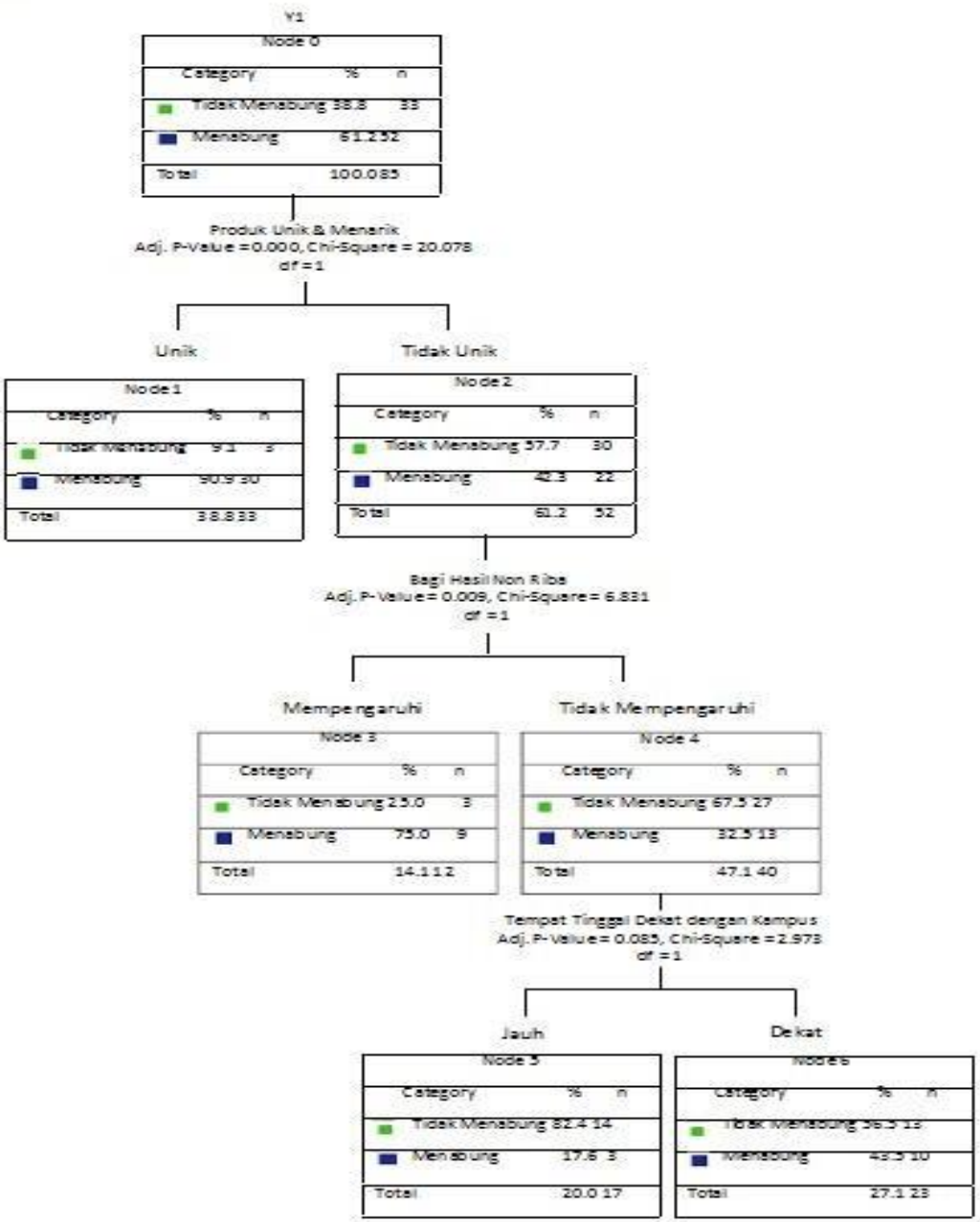

Dari 6 faktor yang memiliki hubungan terhadap minat mahasiswa STEI SEBI menabung di SIB berdasarkan hasil pengolahan dengan CHAID, hanya 3 faktor yang paling signifikan yang memiliki hubungan minat mahasiswa menabung di SIB, yaitu :

1. Produk tabungan yang unik dan tidak unik

2. Bagi hasil non riba

3. Jarak tempat tinggal dengan kampus

Produk tabungan yang unik dan tidak unik tersebut dikategorikan menjadi (1) unik dan (2) tidak unik. Faktor selanjutnya adalah bagi hasil non riba juga dikatagorikan menjadi 2 kategori yaitu, (1) mempengaruhi, (2) tidak mempengaruhi. Berikutnya adalah faktor tempat tinggal yang 
dekat dengan kampus juga dikatagorikan menjadi 2 kategori yaitu, (1) Jauh, dan (2) dekat. Faktor utama yang memiliki keterkaitan dengan minat mahasiswa menabung di SIB adalah Produk yang unik dan tidak unik. Hasil dari dendogram yang menyatakan unik adalah 33 orang $(38,8 \%)$, dan yang menyatakan tidak unik adalah 52 orang $(61,2 \%)$, dari 52 orang tersebut memiliki hubungan terhadap minat mahasiswa STEI SEBI menabung di SIB yang disebabkan bagi hasil non Riba yaitu, 12 orang $(14,1 \%)$ menabung dikeranakan bagi hasil non riba dan 40 orang $(47,1 \%)$ menabung bukan dikarenakan bagi hasil non riba. Adapun dari 40 orang tersebut yang menabung bukan dikarenakan bagi hasil non riba memiliki hubungan dengan minat mahasiswa menabung di SIB dikrenakan tempat tinggal yang dekat dengan kampus yaitu dekat 23 orang $(27,1 \%)$ dan jauh 17 orang $(20 \%)$ sebgaimana yang dapat dilihat pada gambar dendogram di atas.

Adapun produk unik yang ada di Sebi Islamic Bank diantaranya adalah tabungan sakinah dan tabungan skripsi. Produk merupakanpersepsi konsumen yang dijabarkan oleh produsen melalui hasil produksinya yang meliputi barang, kemasan, merek, label, pelayanan, dan jaminan (Tjiptono, 2008 dalam Manongko, 2011, hal. 9). Produk tabungan sakinah adalah produk tabungan untuk pernikahan, dan hanya bisa diambil pada saat nasabah sudah mau menikah. Sehingga dari segi nama dan jenis tabungan ini menjadi unik dalam persepsi mahasiswa. Sama halnya dengan produk tabungan skripsi, yang dikhususkan bagi mahasiswa untuk mempersiapkan tugas akhir perkuliahan. Produk tabungan ini hanya diambil ketika mahasiswa tersebut sudah memasuki tugas akhir. Produk unik tersebutlah yang membuat mahasiswa berminat untuk menabung di Sebi Islamic Bank. Seperti pendapat (Ferdinand, 2002 dalam Bachriansyah, 2011, hal. 16), bahwa salah satu indikator minat konsumen untuk membeli suatu prodak adalah minat preferensial, menggambarkan perilaku seseorang yang memiliki prefrensi utama pada produk tersebut. Bahkan (Dwityanti, 2008 dalam Bachriansyah, 2011, hal. 18) juga berpendapat bahwa naiknya daya tarik terhadap suatu produk yang sudah ditetapkan dapat meningkatkan tingkat konsumsi. Di samping itu, produk SIB juga mempunyai keunikan lain yaitu tidak mempunyai fasilitas ATM yang memungkinkan nasabah untuk melakukan penarikan tunai dengan mudah. Sebagaimana pernyataan responden FGD (focus group discussion) bahwa, mahasiswa yang menabung di Sebi Islamic Bank bertujuan agar terhindar dari sifat boros. Karena dengan menabung di Sebi Islamic Bank para mahasiswa tidak bisa melakukan penarikan tunai dengan menggunakan kartu ATM. Meskipun SIB tidak menyediakan fasilitas ATM yang menyebabkannya seolah ketinggalan perkembangan teknologi, namun dalam persepsi mahasiswa (nasabah), hal tersebut malah menjadi sebuah keunikan. Hasil penelitian (Wibisana dalam Ani Sapariyah, 2009, hal 3) menyimpulkan, bahwa terdapat keberagaman persepsi masyarakat terhadap perbankan syariah. Demikian juga halnya dengan persepsi masyarakat terhadap produk perbankan syariah. 
Sedangkan pendapat mahasiswa yang menganggap bahwa produk tabungan SIB tidak unik yaitu sebesar 61\%. Adapun alasan mahasiswa menganggap tabungan SIB tidak unik, sebagaimana hasil dari FGD bahwa mereka menganggap tabungan SIB biasa-biasa saja, bahkan yang menyebabkan mereka tertarik menabung di SIB adalah sistem bagi hasil dan jarak tempuh yang tidak jauh dari tempat tinggal mahasiswa dengan kampus.

Faktor selanjutnya yang memiliki keterkaitan dengan minat mahasiswa menabung di SIB adalah bagi hasil non riba. Bagi hasil non riba menjadi pilihan mahasiswa menabung di lembaga keuangan syariah terutama di SIB. Seperti yang telah kita ketahui sebagai muslim, bahwa riba adalah termasuk yang dilarang oleh agama Islam. Seperti terdapat dalam Al-Qur'an.

"Padahal Allah telah menghalalkan jual beli dan mengaharamkan riba" (Al-Baqarah: 275).

Sehingga, nasabah atau masyarakat mensikapi perbankan syariah sebagai lembaga keuangan dalam perspektif Islam (Erlin dalam Sapariyah, 2006, hal. 4)

Namun demikian, sebagian besar mahasiswa (47\%) menyatakan bagi hasil non riba tidak memiliki pengaruh terhadap minat mahasiswa untuk menabung di SIB. Sebagaimana dalam FGD yang penulis tangkap dari alasan responden bahwa bagi hasil non riba tidak memiliki pengaruh untuk menabung di Sebi Islamic Bank. Karena menurut mereka yang berpengaruh terhadap minat menabung di SIB adalah jarak tempat tinggal dengan kampus. Karena jarak yang dekat menjadikan mahasiswa dapat bertransaksi di SIB dengan mudah dan cepat. Hal tersebut dapat dilihat dari jumlah total responden yang dekat dengan kampus adalah 23 orang (27\%). Jumlah tersebut lebih besar dari jumlah responden yang memiliki tempat tinggal jauh dari kampus yaitu 17 orang (20\%).

\section{KESIMPULAN}

Hasil darianalisis Chi-Square menyimpulkan, dari 31 indikator ada 6 indikator yang memiliki keterkaitan dengan minat mahasiswa menabung di SIB yaitu, tempat tinggal dekat dengan kampus, pengaruh lingkungan tempat tinggal, produk tabungan yang unik dan tidak unik, sistem bagi hasil non riba, pengaruh uang saku, dan pengaruh banyaknya teman yang menabung. Dari ke enam faktor tersebut ada sebagian faktorfaktor yang memiliki nilai X2 hitung lebih tinggi dari nilai X2 tabel yaitu Produk yang unik dan bagi hasil yaitu sebesar 18,739, nilai tersebutlah yang akan menonjol dari hasil perhitungan CHAID.

Penggunaan metode CHAID sebagai analisis dalam penelitian ini sangat berguna dalam kaitannya menseleksi dan pengkategorian ulang peubah kategorik sehingga terbentuk dendogram sederhana faktor-faktor yang memiliki hubungan terhadap minat mahasiswa STEI SEBI 
menabung di Sebi Islamic Bank. Adapun hasil dari metode CHAID menyimpulkan bahwa faktor utama yang memiliki hubungan terhadap minat mahasiswa STEI SEBI menabung di Sebi Islamic Bank, yaitu faktor unik dan tidak unik, faktor bagihasil non riba, dan faktor tempat tinggal dekat atau jauh dengan kampus.Dimana ketiga faktor tersebut termasuk kedalam variabel Pribadi.

\section{DAFTAR PUSTAKA}

Ali sakti, M.Ec, "Analisis Teoritis Ekonomi Islam", AQSA Publishing, Jakarta, 2007

Adiwarman A. Karim, S.E.,M.B.A.,M.A.E.P., "Ekonomi Mikro Islam", PT. Raja Grafindo Persada, Jakarta, 2007

Agus Sujanto, "Psikologi Umum", PT. Bumi Aksara, Jakarta, 2004

Departemen Pendidikan Nasional, "KAMUS BESAR BAHASA INDONESIA", BALAI PUSTAKA, Jakarta, 2007

Erie Febrian, "Akselerasi Pertumbuhan Perbankan Syariah Nasional", Artikel, UNPAD, Bandung, 2010

Hermawan Kertajaya, "Marketing Mix", Mizan, Bandung, 2006

Imam Ghazali, "Aplikasi Analisis Multivariate dengan Program SPSS", Skripsi, Universitas Diponogoro, Semarang, 2005

Muhammad, M.Ag., "Metodologi Penelitian Ekonomi Islam Pendekatan Kuantitatif", RAJAWALI PERS, Jakarta, 2008

Nurul Huda \& Muhammad Heykal, "Lembaga Keuangan Islam", KENCANA, Jakarta, 2010

Sugiyono, "Statistik Nonparametris untuk Penelitian", ALFABETA, Bandung, 2007

Sugiyono, "Metode Penelitian Bisnis", ALFABETA, Bandung, 2009

Paul M. Johnson, "Kamus Ekonomi-Politik", TERAJU, Jakarta, 2003

Philip Kotler, "Dasar-dasar Manajemen Pemasaran Edisi 3", PT. Midas Surya Grafindo, Jakarta, 1987

"Buku Panduan Akademik 2008-2009", STEI SEBI, Jakarta, 2008

"Company Profail", SEBI ISLAMIC BANK, Depok, 2011 